\title{
Practical Ability Training in Practical Teaching of Electronic Information
}

\author{
Ruilin Li, Jinhua Yu, Xiaolin Pi, Honghong Li \\ Nanchang University Gongqing College, Jiangxi, 332020, China
}

Keywords: Electronic information specialty; practice and innovation ability; training mode; engineering education certification

Abstract: Based on the discussion of the electronic information specialty and its connotation and the understanding of innovation and practical ability concepts and training models, teachers can study the training measures for various universities at home and abroad to improve the practice and innovation ability of electronic information students.

\section{Introduction}

Electronic information major includes electronic information engineering, electronic science and technology, communications engineering, microelectronics science and engineering, optoelectronics information science and engineering, information engineering, six basic majors, radio and television engineering, underwater acoustic engineering, electronic packaging technology, and integrated circuits. Design and integration systems, medical information engineering, electromagnetic fields and wireless technology, radio wave propagation and antennas, electronic information science and technology, telecommunications engineering and management, and application of electronic technology education ten special professional. The connotation construction of electronic information major includes: advanced education and teaching concept, optimized talent training program, high-level teacher team and teaching team, excellent courses and excellent teaching materials, relatively perfect practical teaching system, and teaching management that is conducive to the development of students' individuality. The model is highly praised by the industry and employers for the quality of personnel training in seven areas.

\section{Understanding of practice and innovation ability and training mode}

The ability to practice and innovate is a hot word in these years. What is the ability to practice and innovate? Obviously it contains practical and innovative capabilities. The practical ability mainly refers to the individual psychological characteristics required by people to complete the activity in various practical activities. College students' practical ability refers to the psychological characteristics and behavioral qualities of the students who are receiving specialized higher education in schools and who are involved in their own study, life, and future work and interpersonal relationships. Innovation capability refers to the ability to create new technological possibilities and apply them to economic realisation. In a broad sense, innovation capability is the ability to constantly provide new ideas, new theories, new methods, and new inventions that have 
economic value, social value, and ecological value in the field of technology and various practical activities. The professional competence, practical ability and innovative ability of undergraduates are gradually progressive and in-depth capabilities. Only on the basis of sufficiently strong professional qualities and practical abilities can there be innovation[1].

Practice and innovation ability training involves personnel training model. The talent cultivation model refers to the systematic, definitive model and pattern of the training objectives, training system, training process, and training mechanism defined by the colleges and universities in order to complete the task of talent cultivation under the guidance of certain educational concepts. In other words, the talent cultivation model is a model and a pattern of the four major elements of talent cultivation - the goal of talent training, the talent training system, the talent training process, and the talent training mechanism. Curriculum reform is the key to cultivating innovative ability; classroom teaching is the main channel for cultivating innovation ability; using "science and technology innovation" as the carrier to inspire college students' desire for innovation; giving college students full freedom of choice and providing broad space for innovation; The learning ability of undergraduates is the ultimate goal of cultivating innovative capabilities. This is our consensus on the talent training model[2]. The electronic information practice operation diagram is as follows.

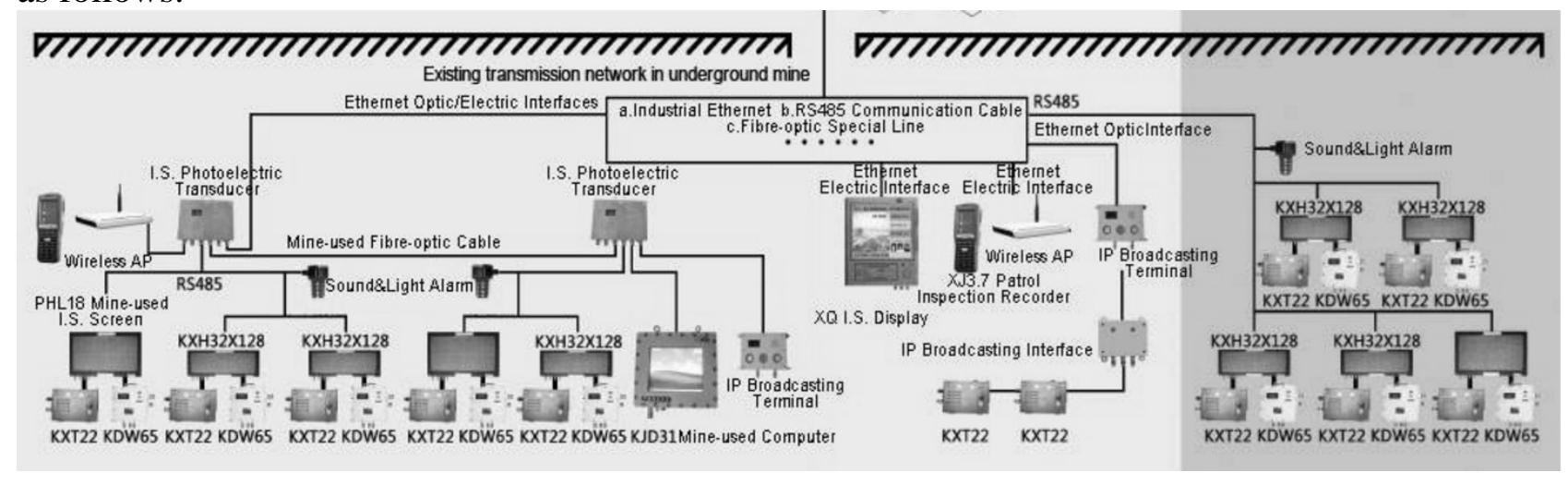

Fig.1 Electronic information practice operation diagram

\section{China's colleges and universities to explore the practice and innovation ability training}

\subsection{Exploration process}

The exploration of the practice and innovation ability of electronic information students in Chinese universities has gone through the following three stages. The first stage is the stage of curriculum development for the cultivation of applied talents. The professional teachers of electronic information and specialty courses are oriented toward cultivating applied talents in classroom teaching, experiments, and curriculum design. Students are the mainstay, improving teaching methods, and theoretical links. Actually, a discussion was conducted on actual application problems and the construction of courses for various professional courses was well done. This stage is in line with the goal of training applied talents at that time. The second stage is the construction phase of the teaching model based on the idea of the big engineering concept. We take the idea of major engineering education as the concept of teaching reform, and innovate to build a new "subject inquiry style" teaching model that highlights the four core characteristics of harmony, synthesis, practice, and quality. The status quo of research on the cultivation of practice and innovation ability is mainly reflected in the first and second stages. The third stage is the stage of curriculum system construction based on output evaluation. The engineering education certification is very inspiring to us. We can implement the curriculum system construction in five aspects from reasonable training 
objectives, clear export requirements, complete content coverage, adequate conditional support, and reliable implementation effects. We use the teaching and research section as a unit and work together to formulate a curriculum system based on output evaluation. With reference to the requirements for certification of engineering education, we have sorted out the knowledge points, reconstructed the framework support of each professional course system, and refined each course and knowledge point. The content and objectives of the teaching, collaborative basic courses and the support and co-construction of various professional courses. The three phases are progressive, and output-based evaluation is our current focus[3].

\subsection{Course}

The courses offered by Chinese colleges and universities for electronic information students have mathematics foundation (higher mathematics, linear algebra, complex functions, probability and statistics, etc.), humanities basics (Marxist-Leninism, philosophy, etc.), electrical courses (circuit analysis, analog electronic technology, basics of digital electronics, high-frequency electronic circuits, modern electronic components, communication courses (signals and systems, digital signal processing, digital communication principles, program-controlled switching, optical fiber communications, mobile communications, etc.), computer courses (computer operations Basics, $\mathrm{C}^{++}$, SCM principles, embedded systems, etc.), foreign language courses (university English, professional English, etc.), and other courses. We have established the boundaries between basic courses and professional courses, clearly and unifying the requirements for each knowledge point. For example, in the teaching objectives, detailed requirements on the mathematical contents of derivatives, Fourier expansions, etc., and requirements for circuit contents of common-base amplifier circuits, field-effect-tube amplifier circuits, etc., are required for multisim, PSpice, Proteus, System View, and Matlab. And other simulation tools. The work in this area is gradual and long-term. Chinese universities have added five credits for innovation and production practice in the teaching process. They have also created innovative open experiment projects to develop students' basic knowledge of engineering, personal ability, interpersonal team capacity, and engineering system capabilities; and each year according to employers. Feedback from students on the revision of teaching plans and building of specialties[4]. The electronic information course schedule formula is as follows.

$$
t_{y}=y_{W}^{T} T\left(U^{T} K_{W} T\right)^{-1} U^{T} k_{\text {new }}=g_{y} k_{\text {new }}
$$

\subsection{Research Paper}

During the period, the electronic information teachers of Chinese colleges and universities also published a number of relevant teaching and research papers, such as the problems existing in setting up school-industry co-construction laboratories for ordinary universities and enterprises, and proposed a multi-enterprise, multi-level school-enterprise cooperation framework to integrate small ones. The school-enterprise cooperation and multi-level cooperation of large-scale enterprises have established a certain scale of school-enterprise cooperation platform, and discussed the implementation plan of establishing an on-campus innovation laboratory according to the multi-level school-enterprise cooperation framework. At the same time, the introduction of CDIO reform ideas, reform of traditional theory teaching, experimental operation and curriculum design methods, in the teaching process emphasizes the student's main status, improve students' initiative in the course, improve students' interest in learning, and cultivate students' innovation Consciousness and hands-on ability. According to the actual conditions of the course, I conducted a theoretical and experimental integrated teaching of high-frequency electronic circuit courses. The 
integration of teaching into teaching experiment is a whole. Multisim simulation is used to introduce teaching tasks. By changing the parameters of the simulation circuit components, observing the simulation waveforms, analyzing and understanding the circuit principles, simplifying the cumbersome theoretical derivation, and enabling students to understand more abstract high-frequency circuits, Student welcome and praise. With the foundation of multisim simulation, the hardware circuit experiment students of the high-frequency electronic circuit experiment course will be more relaxed and effective.

\section{Electronic Information Course Development Prospects}

Judging from the experience of various schools, the training of electronic information students in practice and innovation is a systematic project. From the relationship among the professional qualities, practical abilities, and innovative abilities of college students, the first step is to use engineering education certification as a guide, and to determine the talent training goals based on the characteristics of the colleges, local characteristics, and student foundations.

\section{Summary}

We must refine and optimize the personnel training system, personnel training process, and personnel training mechanism according to the objectives of personnel training, sort out professional curriculum systems, and rationally arrange necessary links such as reform theory teaching, experimental training, curriculum design, practice practice, and graduation design. By leveraging the openness of laboratories, organizing participation in electronic competitions, and giving full play to the enthusiasm of teaching and research rooms, professional teachers, students, and management departments, everyone involved in the project will fully expand the connotation of electronic information and information professionals. All schools must seize the opportunity of undergraduate education and teaching quality assessment, engineering education certification, and vigorously promote the construction of practice and innovation ability training. In practice, we must adopt a teaching model based on goal cultivation, step by step, step by step, and the training of electronic information students in practice and innovation can be targeted and implemented.

\section{References}

[1] Makori, Elisha Ondieki. Micro factors influencing use of electronic information resources among postgraduate students in institutions of higher learning in Kenya[J]. Library Hi Tech News,2015,32(1).

[2] Elisha Ondieki Makori. Micro factors influencing use of electronic information resources among postgraduate students in institutions of higher learning in Kenya[J]. Library Hi Tech News,2015,32(1).

[3] Tintswalo Pascalis Tlakula,Madeleine Fombad. The use of electronic resources by undergraduate students at the University of Venda, South Africa[J]. The Electronic Library,2017,35(5).

[4] Pai Peng,Yong Jiang Zhong,Yu Han Zhang. The Design and Research of Electronic Schoolbag Learning Environment Take "Science of Eyes" of the Science of Primary School for Exam[J]. Applied Mechanics and Materials,2014,3512(651). 